\title{
ANALISIS KRITIS NEW HISTORICISM TERHADAP NOVEL INDONESIA MODERN DALAM KERANGKA SEJARAH SASTRA
}

\author{
Sugiarti \\ FKIP Universitas Muhammadiyah Malang \\ e-mail: atika_umm@yahoo.co.id
}

\begin{abstract}
This study is aimed at (1) describing issues in three novels based on New Historicism in Indonesian literature; (2) exploring the New Historicism Approach which can provide solutions to possible changes in socio-cultural aspects and publishing industry; (3) finding new fundamental concepts which can contribute to the development of Indonesian literature. For this purpose, the study employed the qualitative phenomenological approach with the qualitative content analysis. The data were in the form of sentence fragments relevant to the research focus. Besides, the data were supported by relevant information beyond the text contributing to the existing text. From the analysis, it can be concluded that: (1) the issues that can be revealed based on New Historicism in the three novels are sexuality problems, freedom, sexual deviation, patriarchy, deconstruction and rejection, spiritual aspect, humanity, and creativity in entrepreneurship; (2) the New Historicism Approach uses harsh words, fantasy, language style modification, scientific exploration, philosophy, health problem, and spiritual experience to show something different; (3) concepts that contribute to the history of Indonesian literature are that texts constitute a contestation between some ideologies and social forces in unlimited place and time. Aesthetic issues female writers offer are not only as a new way of expression or another alternative but also show a high motivation to offer different images.
\end{abstract}

Keywords: modern literature, publishing industry, New Historicism

\section{PENDAHULUAN}

Sastra mempunyai struktur yang koheren dan terpadu mengenai hubungan manusia dengan sesamanya dengan alam dan zamannya. Menurut Goldmann (dalam Faruk 1999) sastra merupakan ekspresi pandangan dunia imajiner, dalam usaha mengekpresikan pandangan dunia. Sastra mempunyai struktur yang koheren dan terpadu mengenai hubungan manusia dalam kehidupan.

Sastra sebagai produk kehidupan, mengandung nilai-nilai sosial, falsafi dan sebagainya, baik yang bertolak dari pengungkapan kembali maupun yang merupakan penyodoran konsep baru. Jika diperhatikan bahwa sastra tidak dapat dilepaskan dengan tata nilai kehidupan manusia dan perubahan sosial yang menyertainya. Pada perkembangan sastra, Stephen Greenblatt menawarkan perspektif baru dalam kajian renaisance yakni menekankan keterkaitan teks sastra dengan berbagai kekuatan sosial, ekonomi, politik yang melingkupinya. Dalam spektrum kehidupan manusia yang disebut kebudayaan, maka sastra menduduki tempat yang penting. Dalam berbagai kalangan mengatakan bahwa seseorang yang akrab dengan sastra lebih utuh kemanusiaannya. 
Dalam sejarah sastra Indonesia modern pengarang perempuan seperti Ayu Utami, Dewi Lestari dan Djenar Maesa Ayu merupakan deretan nama yang memiliki proses kreatif monumental sehingga pada gilirannya mendapatkan tempat yang leluasa dalam perkembangan industri penerbitan Indonesia. Kepiawian dalam membingkai peristiwa cerita menyebabkan pengarang-pengarang muda tersebut mendapatkan perhatian yang cukup baik bagi pembaca, satrawan maupun budayawan Indonesia.

Dalam sastra modern munculnya paradigma New Historicism (NH) memiliki daya dan kekuatan yang berpengaruh pada budaya, industri dan sejarah kesusasteraan Indonesia. Pada sisi inilah dia bersaing cukup ketat untuk memberikan tawaran pemikiran "budaya baru" yang selama ini terpinggirkan dan bersaing cukup ketat serta menjadikan sastra sebagai barang komoditas hukum pasar yang berlaku. Selanjutnya pada saat itu pula sejarah sastra menorehkan sesuatu yang cukup monumental yang diakui oleh pengarang-pengarang Indonesia. Sehubungan dengan hal tersebut diperlukan sebuah penemuan teori pengetahuan fundamental antara budaya, industri dan sejarah sebagai langkah awal meletakan dasar akademis dalam rangka membangun institusi-institusi sastra yang lebih proposional dan berdaya saing.

Adapun permasalah dalam penelitian ini mencakup: (1) bagaimanakah isu-isu tematik yang dapat diungkapkan berdasarkan penerapan New Historiscm dalam sastra Indonesia?; (2) bagaimanakah metodologi New Historisicm dapat menjawab persoalan perubahan sosial, budaya, dan industri penerbitan?; (3) bagaimana konsep dasar/temuan yang dapat diangkat dan memberikan sumbangan pada sejarah kesusastraan Indonesia?
Sebagai gejala struktural postrukturalis dianggap bagian postmodernisme. Postrukturalis merupakan tradisi intelektual untuk mengantisipasi berbagai distorsi sistem semantis sehingga karya sastra benar-benar berfungsi dalam kehidupan masyarakat (Ratna, 2004). Postrukturalis merupakan perkembangan positif strukturalisme. Lebih lanjut postrukturalis berkembang karena dipicu kecenderungan mutakhir kehidupan manusia yang berkembang dalam situasi yang serba cepat dan posttrukturalis digunakan untuk memahami gejala kultural secara universal.

Dalam banyak hal poststrukturalisme, postmodernis, dan postrukturalisme di satu pihak dianggap sebagai mazhab yang antihumanis sebab secara terus menerus menghilangkan subjek. Pengertian humanis dalam hubungan ini bukanlah manusia secara keseluruhan melainkan manusia penguasa, manusia hegemonis, seperti kreator (karya seni), kapitalis (ekonomi), dan laki-laki (feminis), termasuk kulit putih (ras) (Ratna, 2004). Pada dasarnya post modernisme, poststrukturalisme dan dekonstruksi memberikan perhatian pada kelompokkelompok yang terpinggirkan, manusia yang tertindas (pribumi, perempuan, petani, buruh dan sebagainya) serta kelompok minoritas.

Dalam arti luas resepsi didefinisikan sebagai pengolahan teks, cara-cara pemberian makna terhadap karya, sehingga dapat memberikan respon terhadapnya. Respon yang dimaksud tidak dilakukan antara karya dengan seorang pembaca, melainkan pembaca sebagai proses sejarah, pembaca dalam periode tertentu (Ratna, 2004). Hal ini memberikan indikasi bahwa pembaca dengan proses sosial yang menyertainya memiliki peranan penting untuk memberikan makna terhadap suatu karya.

Teori resepsi meneliti peran pembaca dalam kesusasteraan, dan kare- 
nanya merupakan perkembangan yang cukup baru dan menarik. Proses pembacaan, bagi teori resepsi selalu bersifat dinamis, pergerakan dan pemekaran yang kompleks sepanjang waktu. Karya sastra menjadi eksis menurut Roman Ingarden karena 'schemata' atau arah umum yang harus diaktualisasikan oleh pembaca. Pembaca akan melakukan 'prapemahaman' tertentu ke dalam karya sastra. Jika proses pembacaan berjalan ekspetasi akan dimodifikasi, dipelajari dan lingkaran hermeneutik bergerak secara keseluruhan dan kembali ke bagian dan mulai berputar. Pembaca akan melakukan pemahaman secara koheren dari teks serta menyeleksi dan mengorganisir elemen-elemen karya menjadi satu kesatuan yang konsisten secara internal (Eagleton, 2006).

Penelitian resepsi hadir karena teks sastra bersifat dinamis. Teks sastra akan bermakna tergantung pembaca atau penerimanya. Karenanya, makna tergantung bagaimana penerima melakukan konkretisasi teks sastra. Dalam melakukan konkretisasi, pembaca biasanya menerapkan sejumlah pengetahuannya. Pengetahuan itu akan membentuk "horison harapan" pembaca pada saat berhadapan dengan teks (Teeuw, 1984). Pandangan Jauss horison harapan pembaca terbagi menjadi dua, yaitu (1) yang bersifat estetis dan (2) tidak estetik (di luar teks sastra). Yang bersifat estetik berupa penerimaan unsur-unsur struktur pembangun karya sastra, seperti: tema, alur, alur, gaya bahasa, dan sebagainya. Yang tidak bersifat estetik sikap pembaca, pengalaman pembaca, situasi pembaca dan sebagainya. Kedua sisi resepsi satra tersebutsama-sama penting dalam pemahaman karya sastra (Jauss, 1982).

Pada perkembangan sekarang ini pengertian industri memiliki cakupan yang cukup luas. Awal mulanya industri mengimplikasikan tergabungnya dua pengertian secara serempak, yaitu 'aplikasi yang keras dan kerja yang bermanfaat'. Pada saat itu menurut Williams (1967), pengertian industri sebagai kualitas manusiawi mulai terdesak oleh pengertiannya sebagai suatu institusi.

Industri dalam pengertian institusi dibangun oleh dua konsep lain , yaitu industrialisme dan revolusi industri (Faruk, 2001). Industrialisme berarti suatu tatanan masyarakat yang didasarkan pada produksi mekanik yang terorganisasi, sedangkan revolusi industri menunjuk pada serangkaian penemuan teknologis dan proses terbentuknya tatanan masyarakat baru yang didasarkan padanya. Hubungan antara produksi yang terorganisasi secara mekanik dengan serangkaian penemuan teknologisasi memberikan pada kata industri suatu acuan kepada institusi-institusi produktif dengan tipe di atas.

Di sisi lain, komoditi-komoditi yang dihasilkan oleh industri budaya diarahkan oleh kebutuhan untuk menyadari nilainya di pasaran. Motif keuntungan menentukan sifat berbagai bentuk budaya. Secara industrial produksi budaya merupakan sebuah proses standardisasi di mana produkproduk tersebut mendapatkan bentuk yang sama pada semua komoditas. Akan tetapi, produksi budaya itu juga menganugerahkan suatu rasa individualitas dalam artian bahwa setiap produk "mempengaruhi suasana individual". Semakin banyak produk kultural yang benar-benar distandardisasikan, semakin banyak pula yang diindividu-alisasikan. Individualisasi merupakan sebuah proses indiologis yang menyembunyikan proses standardisasi (Strinati, 2004: 70).

Industri budaya bersentuhan dengan kesalahan bukan kebenaran, dengan kebutuhan-kebutuhan palsu dan solusi-solusipalsu, danbukannyadengan kebutuhan-kebutuhan dan solusi-solusi 
riil. Industri budaya menyelesaikan masalah "hanya pada permukaan", bukan dipecahkan sebagaimana seharusnya di dunia nyata (Strinati, 2004). Industri budaya menawarkan bentuk bukannya substansi penyelesaian masalah, pemuasan semu atas kebutuhan palsu sebagai pengganti solusi riil berbagai persoalan nyata. Dalam melakukan hal ini, industri budaya mengambil alih kesadaran massa. Wacana dalam bentuk konversasi pun dapat diangkat sebagai model wacana yang mengandung aneka macam fenomena. Dari keseluruhan fenomena tersebut dapat digunakan untuk mengkaji wacana yang lebih luas, misalnya, cerita, pidato politik, novel, dan lain sebagainya.

Betapapun disadari bahwa perkembangan industri budaya termasuk di dalamnya industri penerbitan yang berorientasi pada kepentingan ekonomi, namun keberadaannya tetap memiliki andil yang cukup besar dalam mengembangkan karya sastra Indonesia. Kenyataannya karya sastra akan dapat dinikmati oleh masyarakat apabila karya tersebut telah dicetak atau diperbanyak oleh penerbit. Dengan demikian dapat dikatakan bahwa terjadi keterkaitan yang cukup erat antara karya sastra dengan industri penerbitan dalam rangka memenuhi kebutuhan masyarakat pembaca. Sosio industri sastra telah menjalankan fungsinya sebagai mediator antara penerbit dengan masyarakat pembaca dalam bentuk distribusi atau pemasaran.

Pemasaran sastra seringkali mengabdi pada kepentingan penikmat. Goldman (1977) memberikan gambaran yang berkaitan dengan produksi dan pemasaran sastra seharusnya mampu mengungkap nilai pasar dan nilai guna. Nilai pasar akan selalu dipengaruhi dengan hubungan manusia dengan sastra sebagai komoditi. Hubungan ini amat ditentukan oleh kualitas konkret objek yang dibeli (baca: sastra). Sedangkan nilai guna adalah penjualan teks sastra yang berkaitan dengan kebutuhan pencipta dan pembacanya. Hubungan keduanya sering telah ditukar dengan uang, sehingga pencipta mendapatkan keuntungan material dan pembaca mendapatkan keuntungan material dan spiritual.

\section{METODE}

Berdasarkan acuan teoretik, penelitian ini menggunakan pendekatan kualitatif-fenomenologi, suatu pendekatan dalam studi sastra yang mencoba memahami dan menginterpretasikan fenomena manusia di dalam teks sastra.. Secara lebih operasional, penelitian ini menggunakan prinsip-prinsip metode analisis isi kualitatif yang biasa digunakan untuk memahami pesan simbolik dari wacana atau teks.

Sumber data penelitian ini adalah novel Indonesia modern meliputi: novel Saman karya Ayu Utami, Petir karya Dewi Lestari, dan Nayla karya Djenar Maesa Ayu yang ditunjang dengan berbagai pendapat/persepsi pembaca, pengarang, serta penerbit terhadap ketiga novel tersebut. Adapun data penelitian berupa satuan cerita yang terdapat dalam ketiga novel tersebut serta hasil wawancara yang diperoleh dari pembaca, pengarang dan penerbit. Data penelitian dikumpulkan melalui analisis teks sastra, diskusi dengan teman sejawat. Analisis teks sastra dilakukan untuk menjelajah ke dalam seluruh struktur dan kultur yang tertuang dalam karya sastra (novel). Adapun triangulasi untuk menggali pendapat pembaca (masyarakat sastra) terkait dengan novel Saman, Petir dan Nayla serta respon industri penerbitan dengan peluang pasar yang ada. 


\section{HASIL DAN PEMBAHASAN}

Umumnya kajian NH menunjukkan bahwa ideologi bekerja dalam teks dengan cara yang lebih kompleks, heterogen, tidak stabil, suatu kekuatan yang terus menerus berproses. Sejumlah persoalan tentang proses produksi, reproduksi, apropriasi nilai-nilai yang relevan untuk dilontarkan sebagai permasalahan dalam menganalisis teks. Sejumlah isu-isu tematik yang dapat diungkapkan dalam novel Saman karya Ayu Utami, Petir karya Dewi Lestari, dan Nayla Karya Djenar Maesa Ayu, dirangkai menjadi satu kesatuan sehingga diperoleh gambaran yang lebih komprehensif dalam memahaminya.

\section{Isu-isu Tematik yang dapat Diungkap- kan}

Representasi perilaku dan orientasi seksual yang demikian beragam dan gugatan bahwa stereotipi perempuan pasif, menggambarkan bahwa dalam diri perempuan masih dibebani adanya tata nilai dan konstruksi sosial misalnya, perempuan harus perawan karena itu dia harus menjaga dirinya baik-baik.

Dan di kamar itu, dia nampak sedikit gugup, saya kira, tetapi jauh dari kalut seperti yang saya rasakan sehingga saya sembunyi di kamar mandi ketika pelayan masuk membawa pesanan. Sebab saya ini orang berdosa. Lalu kami berbaring di ranjang yang tudungnya pun belum disibakkan, sebab kami memang tak hendak tidur siang. Dia katakan dada saya besar: saya jawab tidak sepatah katapun. Dia katakan apakah saya siap. Saya jawab, tolong saya masih perawan. (Adakah cara lain) . Dia katakan, bibir saya indah. Ciumlah. Cium di sini. Saya menjawab tanpa kata-kata. Tapi saya telah berdosa. Meskipun masih perawan (Saman, hlm. 4).

Namun perlu dipertegas bahwa teori-teori imitasi tidak membatasi karya seni sebagai reproduksi realitas secara mekanis akan tetapi membuka peluang seniman untuk melakukan proses kreatif sedemikian rupa sehingga teoriteori imitasi yang klasik tetap dapat dipadukan secara baik sesuai dengan kaidah-kaidah umum. Seperti halnya rekontruksi pemikiran tentang stereotipi perempuan telah dihadirkan pengarang dengan citra yang berbeda. Kehidupan modern telah memasuki wilayah sastra dengan mudahnya. Sikap agresif yang awalnya dimiliki oleh laki-laki bergeser kepada perempuan. Nampaknya Ayu menawarkan citra modernitas melalui interaksi antar tokoh dalam memberikan kenikmatan. Laila tokoh perempuan dalam novel Saman bertahap dalam pencarian cinta. Ia berusaha mendapatkan cinta Sihar, laki-laki yang telah beristri. Bahkan, Laila menantang kejantanan Sihar untuk melakukan hubungan spesial dengannya. Keberanian Laila untuk mengambil inisiatif dan tampak agresif akan membuktikan jika laki-laki mudah untuk ditaklukkan..

"Lalu cinta menjadi sesuatu yang salah karena hubungan ini tidak tercakup dalam konsep yang dinamakan perkawinan. Ia sering merasa berdosa pada istrinya. Semakin lama itu semakin mengganggunya, sehingga suatu hari saya begitu kesal sebab beberapa kali ia membatalkan janji, apakah kamu tidak memikirkan bahwa aku juga punya rasa bersalah pada orang tua? Tapi aku tak pernah membatalkan janji karenanya. Ia terkena dan menjawab dengan nada yang agak menggoda, "Kamu menantang? Apa kamu berani kalau aku teruskan 
hubungan ini?" saya terdiam beberapa saat. Barangkali saya memang menantang kejantanannya, dan itu berarti membuktikan ia bisa ditaklukkan (atau ditegangkan, menurut istilah salah seorang teman, Cok). Pada hal saya tidak punya keberanian untuk melakukan yang lebih dari pada ciuman." (Saman, hlm. 27)

Selanjutnya Rousseau dan Goethe (Cassier, 1987: 214) mengungkapkan bahwa dalam seni karakteristik lebih menekankan luapan spontan dayadaya perasaan yang dipadukan dengan reproduksi batiniah, afeksi-afeksi dan emosi-emosi. Dalam banyak teori estetika modern khususnya pemikiran Croce murid Goethe dan pengikut-pengikutnya lebih menekankan pada faktor ekspresi. Filsafat yang yang dikembangkan adalah filsafat roh yang menekankan karakter spiritual murni dari karya seni. Seluruh energi spiritual dikandung dan dihabiskan dalam pembentukan intuisi semata-mata.

Dalam kehidupan manusia di era global semua cara dapat dilakukan sesuai dengan keinginannya Pelanggaran-pelanggaran terhadap "nilai-nilai" yang selama ini telah ditetapkan oleh masyarakat menjadi sesuatu yang biasa. Dalam hal ini, telah terjadi degradasi nilai-nilai yang awalnya bersifat positif. Kondisi ini juga dipengaruhi oleh estetika posmodern yang didukung ekspresi estetis feminis cenderung mencerminkan adanya kesetaraan, pendobrakan terhadap pembedaan sosial antara lakilaki dan perempuan yang dikonstruksi oleh masyarakat tanpa mempedulikan rasa feminin. Hal ini dapat dicermati melalui tokoh Laila ketika berangkat ke New York untuk hal penting yaitu melancarkan pertemuan dengan Sihar laki laki yang diharapkan cintanya. Ia merasa terikat dan berharap segera bebas dari berbagai aturan yang dapat memasung dan memenjarakan dirinya, serta membiarkan hal-hal yang diinginkan terjadi. Kenyataan ini secara metaforis ditunjukkan bahwa gejala-gejala tersebut juga diakibatkan oleh akselerasi kultural yang terjadi dalam masyarakat.

"Tapi akhirnya kami sepakat untuk melihat New York, sebelum ia berangkat ke Texas. Saya tidak tahu mengapa saya begitu cepat mengambil keputusan. Barangkali saya terobsesi pada dia, yang bayangannya selalu datang dan jarang pergi. Barang kali saya letih dengan segala yang menghalangi hubungan kami di Indonesia. Capek dengan nilai-nilai yang kadang seperti di teror. Saya ingin pergi dari situ semua, dan membiarkan hal-hal yang kami inginkan terjadi. Mendobrak yang selama ini menyekat hubungan saya dengan Sihar. Barang kali." (Saman, hlm. 28)

Karena itu fungsi puitis seni dijelaskan sebagai kemampuan seniman "menuangkan habis perasaan-perasaan sesak di dada" dalam hal ini Collingwood menegaskan mengekpresikan emosi tertentu dan mengekpresikannya secara baik, ialah hal yang sama...... Setiap ucapan dan gerak- gerik yang dilakukan ialah karya seni. Kesemuanya itu tidak sekedar bersifat ekspresif, namun juga representatif dan interpretatif (Cassier, 1987).

Novel Petir karya Dewi Lestari mengungkapkan berbagai peristiwa kehidupan dengan berbagai dimensinya. Persolaan praktik budaya mencari dan menciptakan lapangan kerja, perilaku manusia modern, bohemian dan pemberontakan, persoalan pencarian jati diri sampai dengan persoalan spiritualitas. Berikut ini akan digambarkan berbagai praktik budaya yang terjadi pada novel 
Petir, terkait dengan mencari dan menciptakan lapangan kerja dapat diperhatikan melalui kutipan berikut.

"Aku yang belum pernah menulis CV sempat agak bingung juga. Un tung ada buku Sukses Melamar Kerja milik Watti yang tidak terbawa ke Tembagapura. Dan berhubung ini bukan CV biasa, aku tambahkan keterangan unik lain yang sekiranya membuat pihak STIGAN aku memang berpotensi gaib, antara lain: kesetrum listrik waktu umur sembilan tahun dan selamat tanpa cedera, ahli memanggil petir, lolos dari sambaran halilintar, menyetrum seorang dukun sakti. Semoga tambah meyakinkan. Amin." (Petir, hlm. 71).

Aktivitas Elektra menyusun CV merupakan salah satu manifestasi dari keinginannya untuk mendapatkan pekerjaan di STIGAN (sekolah Tinggi Ilmu Gaib Nasional) sebagai asisten dosen. Itu terlihat dari usahanya menambahkan hal-hal unik di dalam CV serta harapannya yang tinggi dalam kata "Semoga tambah meyakinkan. Amin." Usaha mencari pekerjaan di STIGAN tersebut Elektra lakukan karena dia terjebak dalam pengangguran yang panjang, sethingga ingin memliki pekerjaan tetap yang menghasilkan uang untuk kelangsungan hidupnya. Walaupun pekerjaan menjadi asisten dosen di sekolah gaib merupakan hal yang tidak masuk akal. Sama gaibnya dengan perjalanan kehiduapan Elektra.

Sebelum memutuskan untuk melamar pekerjaan di STIGAN, Elektra sudah pernah menjajaki dunia kerja yang bersifat multi level, seperti terlihat dalam lutiapan di berikut.

"Karier pertamaku adalah menjadi kaki-kaki dari seorang tante yang juga kaki-kaki dari seorang pemuda yang mungkin juga masih kaki-kaki dan si $X$, yang sebenarnya tidak terlampau masalah karena kami semua satu saudara dalam perusahaan multilevel Amway. Namun setelah gagal menjaring kaki-kaki untuk diriku sendiri, aku memutuskan untuk mengamputasi karierku di sana." (Petir, hlm 37).

Keikutsertaan Elektra dalam multilevel Amway merupakan bentuk usahanya untuk mendapatkan pekerjaan. Walaupun pada akhirnya, pekerjaan tersebut harus ditinggalkannya karena ketidakmampuannya dalam menggaet orang-orang untuk dijadikan mitra (bawahan) dalam pekerjaannya. Ketidakmampuan dalam hal ini bukan berarti sebelum bekerja atau di luar pekerjaan, akan tetapi ketidakmampuan pada saat Elektra sudah berada dalam Amway, ketika dia sudah mulai bekerja. Hal itu pulalah yang memberikan sinyal bahwa Elektra masih belum berkomitmen untuk benar-benar bekerja atau masih mencari-cari dunia pekerjaan yang tepat untuk dirinya.

Lapangan kerja yang diciptakan Elektra untuk memperbaiki hidupnya terbagi menjadi dua bagian yaitu yang berasal dari pemikirannya sendiri dan berasal dari ide orang lain. seperti dalam kutipan-kutipan berikut:

"Maka kujalankanlah falsafah sederhana. Berhenti berpikir ke luar, tapi bereskanlah dulu ke dalam. Lihatlah rumah ini ... rumah yang berharga miliaran ini ... betapa busuknya, bau, pengap, sumpek. Padahal inilah modal yang bisa kujual sekaligus kubanggakan. Betapa kerennya konsep ini nanti: Elektra, si gadis sebatang kara, mandiri dan tabah mengarungi hidup, tinggal di ru- 
mah besar dan cantik berlokasi strategis. Dan karena mempercantik Eleanor lebih mudah ketimbang mempercantik si Elektra, maka kuputuskan untuk melakukan pembersihan besar-besaran." (Petir, hlm 35).

Kesadaran Elektra terhadap potensi Eleanor merupakan awal terciptanya keinginan untuk menjadikannya sebagai modal atau medan untuk berusaha mandiri. Hal itu karena Eleanor merupakan rumah yang indah dan berlokasi strategis tetapi tidak terawat. Lokasi yang strategis dan model Eleanor yang indah inilah yang membuat Elektra yakin akan sukses menjaring investor untuk bekerja sama dengannya. Pembersihan besar-besaran terhadap Eleanor memeliki arti penting karena salah satu faktor penting dalam menjaring peminat (konsumer) adalah kebersihan dan lokasi strategis.

Selain praktik budaya yang telah diuraikan di atas apabila mencermati novel Petir karya Dewi Lestari nampak pula praktek budaya yang dikukuhkan dalam teks pada pola pikir yang dimiliki oleh tokoh cenderung mengarah pada persoalan pencarian jati diri dalam bentuk keyakinan dan berbagai hal yang berkaitan dengan kepribadian individu. Hal ini dapat diperhatikan melalui tokoh Elektra digambarkan sebagai seorang gadis yang memiliki keanehan, yaitu energi listrik yang terdapat dalam tubuhnya. Keanehan itu membuat Elektra penasaran dan ingin tahu apa sebenarnya yang ada pada dirinya. Kutipan ini dapat diperhatikan pada ungkapan berikut.

"Sekian lama berdiam tepi jendela, memori masa kecilku merasuk masuk. Aku teringat betapa senangnya dulu memandangi kilatan pertir. Aku tidak ingat kenapa. Justru itulah yang ingin kuca- ri tahu. Kalau dulu otakku belum terlalu kritis untuk bertanya, nah sekarang, dengan tumpukan protein telur ayam ini masa sih otak Elektra nggak bisa berkembang sedikit dan mulai penasaran mencari jawaban? Ke-na-pa a-ku suka pe-tir?" (Petir, hlm 45).

Keanehan tokoh Utama Elektra yang sewaktu kecil menyukai petir. Dari kesukaanya itu ia mulai bertanya mengapa ia menyukai petir, dan mencoba mencari jawabanya. Kemudian pada kutipan kedua Elektra mulai bertanya-tanya sesungguhnya apa yang terjadi pada dirinya, kekuatan aneh yang menyerupai listrik yang keluar dari tubuhnya. Dari kedua kutipan kita dapat mengetahui bahwa tokoh Elektra sedang melakukan pencarian jati diri atau sesuatu mengenai dirinya

"Setiap aku berpikir, apa itu? Apa 'itu'? Yang keluar dari tubuhku, atau menumpangi tubuhku, sehingga bisa meng-KO nenek malang itu. Kalau memang bukan listrik, apakah itu penyakit? Apakah aku telah menularkan epilepsi padanya? Bisakah epilepsi menular lewat sentuhan?" (Petir, hlm 59).

"Kamu ternyata lebih maju dari yang Ibu duga. Hebat sekali, decaknya kagum. Kamu makin dekat dengan pintu pencarianmu...." (Petir, hlm 131).

Apa yang menjadi keraguan Elektra mulai mendapat jawaban atas pertanyaan-pertanyaanya selama ini setelah bertemu dengan Ibu Sati yang membimbingnya. Sampai penemuan bahwa dalam tubuh Elektra terdapat kekuatan listrik yang harus dikendalikan yang tergambar pada melalui kutipan berikut dengan mmemberikan pemahaman bahwa kekuatan yang dimiliki Elektra 
dapat diasah dan di kendalikan. Elektra menemukan jawabannya setelah ia bertemu dengan Ibu Sati yang memberikan pengajaran tentang bagaimana menggunakan kekuatan listrik yang ada pada tubuh Elektra.

"Ternyata memang tak ada jawaban yang lebih baik. Jauh di lubuk hati, aku tahu ini bukan karena epilepsy. Aku tahu ini bukan gara-gara tarian memanggil petir. Aku tahu ini tak ada hubunganya dengan kutukan turun-temurun Ni Asih. Sesuatu yang tak beres bersemayam di dalam diriku, entah sejak kapan?. Semua itu telah memilih tubuhku. Tapi, siapa itu? Kalau 'itu' bukan Elektra Wijaya, berati siapa? Siapa sesungguhnya 'aku'?Aduh, kenapa jadi sampai disitu masalahnya..?( Petir, hlm 133).

Di dalam Nayla praktek budaya yang paling dominan dan bahkan memiliki potensi menjadi "cita-cita teks" adalah praktek budaya modern yang serba "free", egoistik dan cenderung nir norma serta kering akan sifat-sifat budaya Timur khususnya Indonesia. Hal ini terlihat dari semua tata laku dan cara berpikir tokoh cerita, baik tokoh utama maupun tokoh pembantu seperti kutipan berikut:

" .... Padahal sebagai sahabatnya, saya tahu Juli sudah tidak perawan semenjak remaja ia suka memasukkan benda-benda ke dalam vaginanya sambil membayangkan perempuan yang ia idamkan. Sekarang pun dengan kekasihnya yang seorang model mereka sering bercinta dengan cara salin memasuki vagina satu sama lain dengan jari mereka (Nayla, hlm 5)

Kutipan di atas menyiratkan ba- hwa terdapat praktik tata laku yang sudah membudaya di zaman modern atau zaman kebebasan yang secara substansi sangat bertolak belakang dengan masyarakat Indonesia asli yang cenderung terikat pada norma-norma susila. Masturbasi dan praktek homoseksual yang dilakukan tokoh Juli dan kekasihnya merupakan hal yang masih tabu di lingkungan masyarakat Indonesia. Hal itu dianggap tidak sesuai dengan fitrah kemanusiaan serta melanggar kodrat yang telah ditetapkan Tuhan yaitu perempuan itu adalah pasangan bagi lakilaki; perempuan itu makhluk mulia karena itu harus dimulyakan oleh laki-laki maupun oleh perempuan itu sendiri dalam semua sendi kehidupan.

"kegaduhan ini tetap saja terasa sepi. Lampu warna-warni berpencar silih berganti seiring dengan suara musik yang menghentak seantero diskotik hingga lorong yang menuju karmar mandi. Para nelayan bertender, dan pengunjung terlihat sibuk dengan kepentingannya sendiri-sendiri. Tak ada yang terlalu peduli. Apalagi jika waktu sudah hampir sudah hampir menginjak dini hari. Hanya ada tawa yang mabuk. Hanya ada mabuk yang limbung. Hanya ada limbung yang lupa. Hanya ada lupa yang sejenak mendapat bahagia.

Tak bagi saya lupa tetaplah nestapa. Bahkan ketika pengaruh alkohol sudah sampai melewati kapasitas otak juga tubuh saya dan mengocok perut.... (Nayla, hlm 3)

Kutipan di atas menggambarkan bagian-bagian aktivitas yang seakan telah menjadi kebutuhan hidup, gaya hidup dan tempat mencari hidup bagi sebagian "orang modern" yaitu: minum minuman keras, seks bebas, tempat ramai (diskotik) dan kebiasaan mengha- 
biskan malam di luar rumah. Dalam hal ini semua tokoh cerita termasuk Nayla terlihat larut dan menikmati aktivitas itu, tanpa ada penolakan atau keraguraguan. Keadaan dan perilaku seperti itu secara otomatis akan membawa imaji kita ke alam " dunia barat" yang sangat mengagungkan eksistensialisme atau kebebasan diri tanpa harus mempertimbangkan norma sosial, agama beserta aturan-aturannya yang dianggap sangat kaku dan mengikat walaupun pada hakikatnya mereka tidak mendapatkan apa-apa selain dari kebahagiaan sesaat yang justru terlahir dari penyiksaan diri terlebih dahulu.

Kebebasan berpikir dan bergerak dalam kutipan secara eksplisit diungkapkan bahwa Nayla sebagai tokoh bercerita langsung dalam hatinya sendiri mengenai obsesi dan cara pandangnya terhadap kehidupan dan laki-laki yang ia kencani. Nayla bebas berpikir dan ia juga bebas bergerak mengabaikan segala peraturan hidup ini. Dia menyamakan laki-laki seperti binatang tanpa memikirkan nama orang yang bercinta dengan binatang. Nayla menyuarakan pergulatan pemikiran dan keinginbebasan si pengarang dari kungkungan tradisi budaya yang lebih mengekang pribadi kaum perempuan, seperti terungkap pada kutipan berikut.

"Semua berjalan cepat. Kami bercinta dalam waktu singkat. Maka dalam waktu sesingkat itu tak ada satu orang pun yang bisa memuaskan saya seperti Juli, tetapi memang bukan sekedar kepuasan kelamin yang saya cari. Saya butuh kepuasaan rohani. Mendengar suara mereka mengerang. Merasakan tubuh mereka menggelinjang. Menyaksikan mereka tak lebih dari seekor binatang sangatlah menyenangkan. ...." (Nayla, hlm 101)
Dalam hal ini struktur sosial yang menjadi sasaran ujung tombak Nayla adalah struktur sosial yang menempatkan laki-laki sebagai "penguasa perempuan" atau yang lebih dikenal dengan budaya patriarkhi. Sedangkan struktur sosial yang cenderung dibela atau disanjung Nayla adalah struktur yang terbebas dan dibebaskan dari semua pengaruh kekuasaan laki-laki. Secara mutlak Nayla tidak membela struktur matriarki karena Nayla juga menyalahkan tokoh Ibu yang melambangkan kekuatan matriarki. Kenyataan ini menunjukkan bahwa Nayla tidak suka sistem budaya patriarki dan juga tidak begitu senang dengan sistem budaya matriarkhi, namun secara berani Nayla menawarkan struktur sosial yang berbasiskan sistem kebebasan dan lebih menitik beratkan kepada perempuan berkuasa bukan kekuasaan perempuan.

Adapun bentuk sanjungan Nayla terhadap kaum perempuan terlihat pada kutipan berikut.

"Ibu memang orang yang kuat. Tak akan pernah saya sekuat Ibu. Saya tak pernah melihat ibu begitu mencintai laki-laki seperti ia mencinta Om Indra. Tapi ketika hubungan mereka berakhirpun, ibu terlihat biasa-biasa saja. Tak pernah saya saksikan air mata meleleh di pipinya seperti teman-teman arisan Ibu yang berkumpul di rumah ketika sedang membicarakan perselingkuhan ....". (Nayla, hlm 111).

Ketegaran dan kekuatan Ibu menerima perpisahan yang paling derita dalam hidupnya pada kutipan di atas merupakan perwujudan pembelajaran kepada kaum perempuan. Perpisahan itu hal wajar yang tidak perlu ditangisi apalagi sampai terpuruk dalam kesedihan dan penyesalan yang berlarutlarut. Kedinamisan dan progresifitas 
yang tinggi dalam kehidupan itulah yang menjadi point terpenting dan paling dibanggakan serta dipromosikan oleh Nayla.

\section{Aplikasi New Historisicm dalam Te- laah Kritis Karya Sastra}

Pada tataran praktis metode $\mathrm{NH}$ mampu mengkolaborasikan antara perubahan sosial, budaya, dan industri penerbitan secara simultan. Hal ini dapat diperhatikan pada paktik-praktik fenomena sosial yang terjadi dalam kehidupan masyarakat.

Novel Saman sifat kolase yang menjadi fondasi komposisi membawa perluasan seni plot yang dibangun secara terbuka. Plot yang tidak linier dibangun dalam susunan yang saling isi-mengisi antara arus realistik dengan stream of consciousness dan saling menunjang penokohan dan karakter tokoh. Lompatan-lompatan plot dan lompatan-lompatan peristiwa menegaskan konsep Persambungan dan gabungan kronik-kronik literer dan cerpen menjadi rangkaian fiksi novel yang menunjukkan bahwa novel merupakan imitasi imitasi otobiografi pengalaman-pengalaman kemanusiaan yang mendapatkan tafsiran kreatif.

Demikian pula yang terjadi pada novel Petir karya Dewi Lestari. Pemikiran yang diungkapkan lebih mendominan kerangka pikir dalam membangun keyakinan akan sesuatu yang ada pada dirinya. Kekuatan itulah yang menjadikan individu mampu melakukan sesuatu yang bermanfaat pada orang lain. Di samping itu, persolaan praktik budaya mencari dan menciptakan lapangan kerja, perilaku manusia modern, bohemian dan pemberontakan, persoalan pencarian jati diri sampai dengan persoalan spiritualitas diungkapkan secara sederhana dan meyakinkan. Penggunaan stilisasi yang dipadu dengan alam, serta pengungkapan sains, filsafat dan kese- hatan.

Seperti halnya pemikiran yang ditawarkan Djenar Mahesa Ayu dalam novel Nayla. Novel Nayla merupakan sebuah representasi perubahan sosial akibat modernisasi yang diungkapkan pengarang secara total. Tawaran-tawaran nilai kebaruan yang diungkap dalam novel tidak lagi menjadi sesuatu yang dianggap "tabu" melainkan sesuatu yang biasa ditemui pada kehidupan masyarakat modern yang identik dengan nilainilai kebebasan bertindak, berpikir, dan berperilaku. Nilai-nilai yang identik itu telah menyatu dalam kerangka pikir tokoh dalam mengekplorasi identitasnya secara utuh.

Di dalam novel Nayla ini diceritakan tentang perjalanan hidup seorang anak perempuan bernama Nayla. Nayla mengalami kekerasan dan pelecehan seksual ketika dia masih kecil. Lewat pelariannya, Nayla bekerja sebagai lighting di sebuah diskotik, dan disinilah dia bertemu dengan Juli, seorang perempuan yang akhirnya dipilih menjadi kekasihnya. Setelah dewasa Nayla semakin mempunyai pemikiran akan berbagai hal khususnya masalah ketidakadilan yang diciptakan masyarakat untuk kaum perempuan, dan dia menuangkannya lewat tulisan-tulisan yang dia buat. Berbagai macam masalah seksualitas dan ketidakadilan gender tercermin dalam novel ini. Ada satu kalimat yang sarat nilai edukasi, baik sosial maupun individu. Meskipun mengangkat tema seksualitas, pengarang tetap tidak mengumbarnya begitu saja.

Sebutan sastra "pendobrak" ini barangkali memang tidak berlebihan. Karya-karya Djenar Maesa Ayu sepertinya hendak melawan budaya patriarkis yang begitu mengakar sekian lama dan bahasa yang digunakan cenderung vulgar. Tidak hanya itu, di dalam karya sastranya juga banyak membicarakan persoalan seksualitas yang dianggap 
"menyimpang" seperti hubungan seks di luar nikah, masturbasi, sadomasokisme, dan seks bebas (free sex).

Ayu Utami, Djenar Maesa Ayu dan Dewi Lestari, oleh karena ia hidup di zaman yang berbeda maka ia menghadirkan sesuatu yang berbeda pula dalam teks sastra (novel). Pengalaman dan pengembaraan batinnya menyebabkan mereka menghadirkan sesuatu yang berbeda dengan yang lain. Bagaimana mereka menghadirkan nafas teks yang kental dengan sebuah realitas kehidupan yang "dihiddenkan" dalam rangkaian peristiwa yang unik sehingga mampu mengajuk emosi pembaca untuk menikmatinya.

Dari sisi perpektif industri penerbitan karya-karya Ayu Utami, Dewi Lestari dan Djenar Maesa Ayu menjadikan karya-karya monumental yang benar-benar menjadi perhatian industri penerbitan. Meskipun dikemas dengan gaya bahasa yang kurang baku dan agak rumit (Ayu Utami), namun pasang pasarnya tetap banyak sehingga oplah cetaknya cukup besar. Industri penerbitanpun kritis dalam melihat produk karya yang dihasilkan oleh pengarang yang memiliki perbedaan dengan penulis-penulis yang lain. Diakui atau tidak bahwa gaya penulisan Ayu Utami, Dewi Lestari dan Djenar Maesa Ayu cenderung ke postmodern dan postkolonialis sehingga karya (novel) tersebut dianggap sebagai novel monumental yang hadir pada dekade 2000-an. Gaya penceritaannya lebih mengarah pada kehidupan masyarakat yang serba modern dalam pencarian jati diri yang sesungguhnya yang terkadang terjadi benturan dengan tradisi-tradisi.

\section{Kontribusi terhadap Sejarah Sastra In- donesia}

Gaya penceritaan yang diangkat nampak bersifat agak vulgar dan absurd memberikan daya tarik pembaca untuk mengikutinya secara serius. Sistem penguasaan mutlak itu akhirnya membuahkan eksploitasi separatis terhadap bagian yang merupakan hak perempuan. Kebencian terhadap perilaku-perilaku yang tidak adil. Sistem sosial yang ditawarkan adalah struktur sosial yang berbasiskan sistem kebebasan yang lebih menitik beratkan kepada perempuan berkuasa bukan kekuasaan perempuan. Ketika pesona pencintraan lebih penting daripada kedalaman pencerahan dan saat kejungkirbalikan lebih menarik perhatian daripada ketertiban. Karya-karya demikian seakan mengerti semangat zaman dan mengetahui "kebutuhan" masyarakat.

Saman karya Ayu Utami menghasilkan makna yang mampu menjelaskan keprihatinan utama para tokoh perempuan, yaitu mendobrak pembatasan baik oleh tradisi, tatanan sosial, dan sebetulnya juga agama dalam hal yang berkaitan dengan seksualitas (ketubuhan, keperawanan, hubungan seksual, hasrat seksual, perkawinan, perselingkuhan, dan perkosaan).Penulisan tubuh perempuan (di antaranya kelamin) dan sebagainya, tak sekadar "ditangkap" sebagai tubuh itu sendiri, adalah karya-karya yang dari tubuhnya dapat memantulkan ruang tempat manusia bercermin dan mengukur hidupnya dengan pikiran.

Dewi lestari melalui novel Petir telah mencoba menawarkan pemikiran tradisional versus kemodernan. Kekuatan zaman, kemodernan, manusia millinium, selalu mewarnai dalam kehadiran tokoh cerita. Kekuatan listrik dalam Elektra merupakan kekuatan kemodernan. Pengfungsian energi yang ada dalam tubuh manusia melalui angin dan udara dengan keheningan dan pemusatan pemikiran. Tokoh $\mathrm{Bu}$ Satti mampu menjadi pengemban antara tradisi dan kemodernan. Kemodernan 
ini terkait dengan teknologi informasi. Bagi manusia yang mampu menguasai kemodernan akan mampu menguasai dunia secara material.

Kekuatan yang dihadirkan oleh Djenar Maesa Ayu adalah mengungkapkan hal yang tabu dengan bahasa yang vulgar. Di samping itu juga mengungkapkan realita yang sangat tidak disukai oleh kaum lelaki, serta melakukan perlawanan terhadap budaya patriarkhi.

Konsep dasar yang dapat diangkat untuk memberikan sumbangan pada sejarah sastra Indonesia adalah kehadiran teks merupakan sebuah pertarungan berbagai ideologi dan kekuatan sosial yang memiliki dimensi ruang dan waktu tak terbatas. Persoalan estetika yang ditawarkan perempuan pengarang bukanlah sekadar temuan cara ucap yang bagus dan alternatif tetapi juga keberanian mengarungi sesuatu yang menawarkan kesan lain. Di samping itu, Ayu Utami, Dewi Lestari dan Djenar Maesa Ayu telah memberikan sumbangan berarti dan bermakna bagi perkembangan novel Indonesia dilihat dari karakteristik karya mereka, keunikan kepeloporan karya mereka. Meskipun diakui jumlah perempuan pengarang relatif sedikit apabila dibandingkan dengan laki-laki pengarang.

\section{SIMPULAN}

Berdasarkan hasil analisis dan pembahasan dapat disimpulkan hal-hal sebaga berikut. Pertama, isu-isu yang dapat diungkapkan berdasarkan penerapan New Historiscism dalam novel Saman karya Ayu Utami, Petir karya Dewi Lestari dan Nayla Karya Djenar Maesa Ayu adalah adalah isu seksualitas, kebebasan hidup, penyimpangan seksualitas, pembongkaran budaya patriarkhi, spiritual, dan humanisme. Kedua, penerapan metode New Historiscism dapat diperhatikan melalui lompatanlompatan plot dan lompatan-lompatan peristiwa menegaskan konsep persambungan dan gabungan kronik-kronik literer dan cerpen menjadi rangkaian fiksi novel yang menunjukkan bahwa novel merupakan imitas otobiografi pengalaman-pengalaman kemanusia yang mendapatkan tafsiran kreatif. Selain itu penggunaan plot sorot balik serta gaya pengungkapan vulgar, kaya fantasi, penggunaan stilisasi yang dipadu dengan alam, serta pengungkapan sains, filsafat dan kesehatan.

\section{UCAPAN TRIMA KASIH}

Artikel ini diangkat dari penelitian mandiri swadana yang dilaksanakan pada tahun 2008-2009. Ucapan terima kasih disampaikan kepada para mahasiswa yang telah membantu pelakasanan pengumpulan data dan kepada mitra sejawat yang telah membantu kegiatan verifikasi dan triangulasi data dan hasil penelitian.

\section{DAFTAR PUSTAKA}

Aminuddin. 1990. Pengembangan Penelitian Kualitatif dalam Bahasa dan Sastra. Malang: YA3.

Berger, Peter L dan Thomas Lukman . 1990. Tafsir Sosial atas Kenyataan. Jakarta: LP3ES

Berger, Peter L. Brigitte Berger. 1992. Pikiran Kembara: Modernisasi dan Kesadaran Manusia. Yogjakarta: Kanisius

Berten, Kees. 1983. Masalah "Dunia" dalam Filsafat Manusia. Jakarta: Gramedia

Budianta, Melani. 2006. “Budaya, Sejarah , dan Pasar. New Historicism dalam Perkembangan Kritik Sastra". Dalam Jurnal Susastra 3. Jakarta: HISKI Yayasan Obor Indonesia

Derrida, Jaques. 2002. Dekontruksi Spiritual: Merayakan Ragam Wajah Spiritual. Jakarta: Jalasutra 
Eagleton, Terry. 2006. Teori Sastra Sebuah Pengantar Komprehensif. Yogyakarta : Jalasutra.

Faruk HT. 2001. Beyond Imagination Sastra Mutakhir dan Ideologi. Yogyakarta: Gama Media.

Goldmann, Lucian. 1981. The Epistemology of Sosiology. New York : Praeger Publisher.

Kartodirdjo, Sartono. 1992. Pendekatan Ilmu Sosial dalam Metode Sejarah. Jakarta: Gramedia

Kartono, Kartini. 1990. Psikologi Umum. Bandung: C.V. Mandar Maju

Koentjaraningrat . 1981. Pengantar Ilmu Antroplogi . Jakarta: Rineka Cipta.

Laurenson, Diana dan Alan Swingewood. 1972. The Sosiologi of Literature. London: Paladin

Lestari, Dewi. 2005. Supernova: Petir. Bandung: Truedee

Pattyna, F. 1982. Pengantar Psikologi Umum. Surabaya: Usaha Nasional

Ratna, Nyoman Kutha. 2004. Teori, Metode, dan Teknik Penelitian Sastra. Yogjakarta: Pustaka Pelajar.

Ratna, Nyoman Kutha. 2005. Sastra dan Cultural Studies. Representasi Fiksi dan Fakta. Yogjakarta: Pustaka Pelajar

Robertsoon, Roland. 1988. Agama dalam Analisa dan Interprestasi Sosiologi. Jakarta: Rajawali Pers
Satoto, S; Zainuddin Fananie (Ed). 2000. Sastra Ideologi Politik dan Kekuasaan. Surakarta. Muhammadiyah University Press

Selden, Raman. 1993. Panduan Pembaca. Teori Sastra Masa Kini. Terjemahan Rahmat Djoko Pradopo. Yogyakarta : Gadjah Mada University Press.

Sumardjo, Yakob. 1999. Konteks Sosial Novel Indonesia 1920-1977. Bandung: Alumni

Suyitno. 1986. Sastra Tata Nilai dan Eksegesis. Yogyakarta: PT Hanindita

Strinati, Dominic. 2004. Popular Culture. Pengantar Menuju Teori Budaya Populer. Yogyakarta: Bentang Pustaka.

Teeuw, A. 1979. Sastra Baru Indonesia. Malaya: University Malaya.

Teeuw, A. 1984. Sastra dan Ilmu Sastra. Jakarta: Balai Pustaka.

Teeuw, A. 1994. "Nikmat Sastra Lama Bagi Sastra Baru Tentang Persambungan Sejarah dan Penciptaan Sastra". Jurnal Kebudayaan Kalam. Edisi 2 1994. Jakarta: Pustaka Utama Grafiti.

Waluyo, Herman J. 1992. Penelitian Pendidikan Bahasa dan Sastra. Surakarta : Sebelas Maret University Press

Wellek Rene dan Austin Warren. 1985. Teori Kesusastraan. Terjemahan Melani Budianta. Jakarta : Gramedia. 